\title{
KORELASI ANTARA KONDISI LINGKUNGAN FISIK, SOSIAL-BUDAYA DAN SOSIAL-EKONOMI DENGAN PARTISIPASI WARGA MASYARAKAT DALAM PNPM-MP
}

\author{
Hamzah Bona \\ Program Studi Magister Kajian Pariwisata, \\ Sekolah Pascasarjana - Universitas Gadjah Mada
}

\begin{abstract}
The purposes of this study is to identify the correlation of physical environment, sociocultural and socio-ecomic to the community participation by the National Program of Community Empowerment for rural areas empowering (Rural-PNPM) The research was conducted by survey method and using independent variables such as physical environment, socio-culture and socio-economic factor while the dependent variable is the community participation. Respondents are the people who particpipate directly and or indirectly to the implementation of the Rural-PNPM. They are consisting of 100 respondents by using systematic sampling technique. The data were then processced and analyzed by using simple linear regresion, multi linear regresion. This analysis aimed to find out the correlation of each independent variable to the dependent variable, and to predict changing its variables. To do this stastical analysis, SPSS 17.

The results showed that level of community participation is in mid category $61 \%$ and the inferensial statistics suggests that: First, the correlation between indenpendent and dependent variabel are quite strong category and positive with correlation cofficien value (R) 0,519 . Second, determination coefficient value ( $R$ square) reaches $(0,353)$. It indicates that the physical environment; socio-cultural and socio-ecomic factor contribute 35.3 persent to the level of community participation at the tourism development. Third, level of community participation influenced by physical environment, socio-culture and socioeconomic factor. They are sanitation, age, education, activity in social organization with regression coefficient $\left(Y=0,509+0,201 X_{1}+0,152 X_{2}+0,451 X_{3}+0,224 X_{4}+0,006 X_{5}\right)$. Fourth, in partially, sanitation, education level, activity in social organization and family income variables have weak positive effect and significant to the level of community partisipation, while age a very weak positive but not significant.
\end{abstract}

\section{Keywords:}

physical environment, socio-culture, socio-economic and community participation

\section{INTISARI}

Penelitian ini bertujuan untuk mengetahui faktor lingkungan fisik, sosial-budaya dan sosial-ekonomi terhadap tingkat partisipasi masyarakat pada pengembangan pariwisata melalui Program Nasional Pemberdayaan Masyarakat Mandiri Perdesaan (PNPM-MP) di Desa Lohia Kecamatan Lohia Kabupaten Muna. Penelitian ini dilakukan dengan metode survei dan menggunakan variabel bebas, seperti faktor lingkungan fisik, sosial-budaya dan sosial ekonomi, sedangkan variabel terikat adalah partisipasi masyarakat. Responden adalah masyarakat yang berpartisipasi langsung dan atau tidak langsung terhadap 
pelaksanaan PNPM-MP yang berjumlah 100 orang, dengan menggunakan teknik sampling sistematis. Data yang diperoleh selanjutnya diolah dan dianalisis dengan menggunakan regresi linier sederhana, regresi linier ganda dan metode tabulasi silang. Tujuan analisis adalah untuk mengetahui korelasi masing-masing variabel bebas terhadap variabel terikat, serta untuk memprediksi perubahan yang terjadi terhadap variabelnya. Untuk keperluan statistik digunakan SPSS 17.

Hasil penelitian menunjukkan bahwa tingkat partisipasi masyarakat dalam pengembangan pariwisata adalah kategori sedang $61 \%$ dan secara inferensial menunjukkan bahwa: pertama, hubungan antara variabel bebas dan variable terikat adalah cukup kuat dan signifikan dengan koefisien $(r)=0,519$. Kedua, nilai koefisien determinasi (R square) $=0,353$. Hal ini menunjukkan faktor lingkungan fisik, sosial-budaya dan sosial-ekonomi berpengaruh terhadap tingkat partisipasi masyarakat pada pembangunan pariwisata sebesar 35,3\%. Ketiga, tingkat partisipasi masyarakat dipengaruhi oleh lingkungan fisik, sosial-budaya dan sosial-ekonomi faktor, seperti: sanitasi, umur, pendidikan, organisasi kemasyarakatan dengan koefisien regresi $(Y=0,509$ $\left.+0,201 X_{1}+0,152 X_{2}+0,451 X_{3}+0,224 X_{4}+0,006 X_{5}\right)$. Keempat, secara parsial variable sanitasi, tingkat pendidikan, keterlibatan dalam organisasi kemasyarakatan dan pendapatan berpengaruh lemah positif dan signifikan, sedangkan umur berpengaruh sangat lemah positif namun tidak nyata. Kelima, terdapat keterkaitan lemah dan signifikan antara jenis pekerjaan terhadap tingkat partisipasi masyarakat dalam pengembangan pariwisata (koefisien kontingsinya 0,313 dan signifikan 0,028<0,05).

\section{Kata Kunci:}

lingkungan fisik, sosial-budaya, sosial ekonomi dan partisipasi masyarakat

\section{PENDAHULUAN}

Pelaksanaan sistem desentralisasi yang lebih mengedepankan prinsip otonomi daerah menuntut semua pihak untuk melakukan perubahan dan pemahaman tentang tugas dan kewenangan pemerintah daerah. Pemerintah daerah bertugas dan bertanggung jawab untuk mencari, mengolah, dan mengembangkan pariwisata. Pemerintah juga berwenang mengatur dan mengurus kepentingan masyarakat setempat menurut prakarsa sendiri berdasarkan aspirasi masyarakat. Peran serta masyarakat merupakan upaya peningkatan kesadaran dan kepedulian masyarakat terhadap pengelolaan sarana sanitasi dasar ${ }^{1}$. Sasaran yang diharapkan dalam peningkatan pengelolaan sanitasi dasar, khususnya pembangunan penampung air hujan (PAH) dan mandi cuci kakus (MCK) umum adalah mengusahakan warga masyarakat untuk berperan serta secara aktif. Untuk mencapai sasaran tersebut,

Kustiah, T. 2005. Pengelolaan Sanitasi Berbasis Masyarakat, Kolokium, Bandung. pembangunan sanitasi dasar dan pengelolaannya perlu didasarkan pada prinsip pendekatan partisipatif dalam semua aspek. Pendekatan partisipatif itu sedapat mungkin ditetapkan oleh warga masyarakat di tingkat bawah atau yang berbasis masyarakat.

Anggota masyarakat secara individual ataupun secara kelompok merupakan salah satu aktor pembangunan yang penting. Penduduk, terutama penduduk asli yang tinggal di kawasan wisata, menjadi salah satu pemain kunci dalam pariwisata karena merekalah yang akan menyediakan sebagian besar produk wisata dan menentukan kualitas produk wisata.

Kebijakan pemerintah dalam program pemberdayaan masyarakat seperti PNPM$\mathrm{MP}$, berupa proses perencanaan yang didasarkan pada pemikiran bahwa masyarakat merupakan sumber informasi yang dapat dijadikan pertimbangan dalam pembuatan keputusan. Gagasan dan informasi dari masyarakat itu sangat membantu stakeholders pengambil keputusan untuk menyusun rencana peruntukan, penyediaan, dan penge- 
lolaan wisata secara berkelanjutan. Dengan demikian, keputusan yang dihasilkan tepat dan diterima oleh masyarakat. Selain itu, akan berkurang hambatan yang mungkin timbul. Pada tahap pelaksanaan, partisipasi masyarakat didasarkan atas pemikiran bahwa pengelolaan pariwisata diperuntukkan bagi kesejahteraan dan kemakmuran rakyat. Oleh sebab itu, masyarakat harus turut mengurus dan mengelola pariwisata.

Pengembangan pariwisata berkaitan dengan munculnya pemahaman dan kesadaran bahwa Indonesia memiliki cukup banyak potensi sumber daya alam yang dapat dijadikan sebagai daya tarik wisata. Di Sulawesi Tenggara, khususnya Kabupaten Muna, terdapat obyek wisata yang potensial untuk dikembangkan yaitu Danau Napabale, terletak di Desa Lohia Kecamatan Lohia, berjarak $+20.30 \mathrm{~km}$ dari ibukota kabupaten dan ramai dikunjungi wisatawan lokal. Manajemen dilakukan oleh pemda dinilai belum optimal. Warga masyarakat yang semestinya diuntungkan, masih terabaikan dan belum mendapatkan manfaat secara memadai. Hal ini dilihat dari munculnya situasi kerawanan sosial, seperti warga yang mabuk-mabukan di kawasan danau. Efeknya yang timbul adalah perkelahian warga masyarakat dengan pengunjung. Selain itu, ada penolakan warga masyarakat terhadap kebijakan pengganti transportasi danau dari perahu kayu menjadi perahu fiber. Pembangunan sarana jalan yang melintasi bibir danau sebagai program pemerintah mengakibatkan kurangnya pendapatan tukang perahu.

Rendahnya partisipasi masyarakat juga disebabkan oleh rendahnya pengetahuan tentang program pemberdayaan yang digulirkan pemerintah. Penyebabnya ialah sosialisasi program cenderung menuju satu arah dan memandang warga masyarakat sebagai obyek. Mereka tidak dilibatkan dalam perencanaan dan sosialisasi program. Warga masyarakat akan mempercayai program pembangunan jika mereka dilibatkan dalam proses perencanaan, pelaksanaan, pengawasan, dan pemanfaatan sehingga akan lebih mengetahui selubeluk dan merasa memiliki program tersebut ${ }^{2}$.

Pariwisata dapat dilihat dari sisi manajemen yakni perencanaan, pelaksanaan, pengawasan, sampai dengan pemanfaatan. Oleh karena itu, penelitian ini menganalisis faktor lingkungan fisik, sosial-budaya, dan sosial-ekonomi yang mempengaruhi tingkat partisipasi masyarakat terhadap pengembangan pariwisata di Desa Lohia, Kecamatan Lohia, Kabupaten Muna, Provinsi Sulawesi Tenggara.

\section{PERUMUSAN MASALAH}

Rumusan masalah dalam penelitian ini adalah: (1). Apakah ada pengaruh faktor lingkungan fisik terhadap tingkat partisipasi masyarakat dalam pengembangan pariwisata di Desa Lohia? (2). Apakah ada pengaruh faktor sosial-budaya terhadap tingkat partisipasi masyarakat dalam pengembangan pariwisata? (3). Apakah ada pengaruh faktor sosial-ekonomi terhadap tingkat partisipasi masyarakat dalam pengembangan pariwisata?

\section{TUJUAN PENELITIAN}

Tujuan Penelitian adalah: 1). Mengetahui pengaruh faktor lingkungan fisik terhadap tingkat partisipasi masyarakat dalam pengembangan pariwisata di Desa Lohia? 2). Mengetahui pengaruh faktor sosial-budaya terhadap tingkat partisipasi masyarakat dalam pengembangan pariwisata? (3). Mengetahui pengaruh faktor sosial-ekonomi terhadap tingkat partisipasi masyarakat dalam pengembangan pariwisata?

\section{METODE PENELITIAN}

Penelitian ini merupakan jenis penelitian survei. Variabel bebas yang dilibatkan meliputi faktor lingkungan fisik, faktor sosialbudaya, dan faktor sosial-ekonomi. Untuk kepentingan analisis, variabel tersebut dijabarkan menjadi variabel-variabel penjelas

Sulistiyani. 2004. Kemitraan dan Model-Model Pemberdayaan, Gaya Media. Yogyakarta. 
yang lebih operasional: variabel lingkungan fisik ialah sanitasi $\left(X_{1}\right)$, variabel sosial-budaya ialah umur $\left(X_{2}\right)$, tingkat pendidikan $\left(X_{3}\right)$, keterlibatan dalam organisisasi kemasyarakatan $\left(X_{4}\right)$, dan faktor sosial-ekonomi ialah pendapatan $\left(X_{5}\right)$.

Populasi penelitian adalah masyarakat yang berpartisipasi langsung maupun tidak langsung terhadap Program Nasional Pemberdayaan Masyarakat Mandiri Perdesaan PNPM-MP. Sampel penelitian adalah sebagian dari populasi yang diambil sebagai sumber data, yang dapat mewakili seluruh populasi. Sampel juga merupakan sebagian dari jumlah dan karakteristik yang dimiliki oleh populasi tersebut. ${ }^{3}$ Contoh, Apa yang dipelajari dari sampel tersebut, kesimpulannya akan digunakan untuk menggeneralisasikan atau diberlakukan terhadap seluruh populasi.

Untuk menentukan sampel penelitian, digunakan teknik sampling sistematis yaitu pengambilan sampel dengan cara mendaftarkan seluruh populasi sasaran dan mengambil sampel berdasarkan urutan dari anggota populasi yang telah diberi nomor urut ${ }^{4}$. Karakteristik populasi penelitian ini bersifat homogen dan tidak terlalu tersebar secara geografis. Atas dasar karakteristik populasi ini, jumlah sampel yang diambil adalah 100 orang. Selain itu, dalam sebuah penelitian, tidak terdapat batasan yang secara tegas mengatur seberapa besarnya sampel yang harus diambil. Namun, pada prinsip ada halhal yang harus diperhatikan untuk menentukan besarnya sampel tersebut yaitu derajat keseragaman populasi, tingkat ketepatan yang dikehendaki, rencana analisis yang akan digunakan, dan kemampuan peneliti (waktu, tenaga, dan biaya) untuk menyelesaikannya.

Pengumpulan data dilakukan dengan cara: (1). Data primer, diperoleh melalui kuesioner yang berisikan daftar petanyaan

Sugiyono. 2007. Statistika untuk Penelitian. Alfabeta. Bandung.

4 Sugiyono. 2007. Statistika untuk Penelitian. Alfabeta. Bandung. yang telah disusun sesuai dengan tujuan penelitian; (2). Data sekunder, pengumpulan data sekunder dilakukan dengan mengambil data BPS Kabupaten Muna dan kantor desa, yaitu data yang berkaitan dengan demografi desa.

Instrumen yang digunakan untuk mendapatkan data variabel-variabel penelitian adalah kuesioner. Isi kuesioner terdiri dari sejumlah pertanyaan yang memuat semua indikator dari variabel-variabel penelitian dan dirancang untuk digunakan dalam wawancara dengan responden. Penentuan skor perta-nyaan pada kuesioner menggunakan "Skala Likert" dengan jawaban jenjang 3 (1, $2,3)$. Menurut para ahli ${ }^{5}$ pada masyarakat pedesaan jawaban kuesioner yang lebih sesuai adalah berjenjang 3 (tiga).

Pengujian jenis data interval dan rasio pada variabel bebas adalah sanitasi $\left(X_{1}\right)$ umur $\left(X_{2}\right)$, pendidikan $\left(X_{3}\right)$, keaktifan dalam organisasi kemasyarakatan $\left(X_{4}\right)$ dan pendapatan $\left(X_{5}\right)$. Hipotesis 1, 2, 3, 4, dan 5 secara berturut-turut menggunakan analisis regresi linier sederhana dan regresi berganda ( $\mathrm{mul}$ tiple regression analysis). Tujuan analisis ini, antara lain, adalah untuk mengetahui persamaan garis yang menunjukkan hubungan antara variabel bebas dengan variabel terikat, mengetahui besarnya pengaruh perubahan nilai variabel $X$ terhadap perubahan nilai variabel $Y$, memprediksi nilai suatu variabel dari nilai variabel lain yang diketahui, dan menentukan proporsi pengaruh variabel bebas terhadap variabel terikat atau koefisien determinasi. ${ }^{6}$

\section{HASIL PENELITIAN DAN PEMBAHASAN}

\section{Karakteristik Lokasi Penelitian}

Penelitian dilakukan di Desa Lohia, Kecamatan Lohia, Kabupaten Muna, Provinsi Sulawesi Tenggara. Desa Lohia selain merupakan salah satu desa wisata, juga

\footnotetext{
Singarimbun, M., Efendi, S. 1995. Metode Penelitian Survey. LP3ES. Yogyakarta.

6 Kusmayadi. 2004. Statistika Pariwisata Deskriptif. Prenhallindo. Jakarta.
} 
merupakan ibukota kecamatan dengan luas wilayah $8,23 \mathrm{~km}^{2}$ atau $16,52 \%$ dari total luas wilayah Kecamatan Lohia. Jarak ibukota desa ke ibukota kabupaten adalah 20,30 km, dengan suhu iklim tropis rata-rata antara 25 - $27^{\circ} \mathrm{C}$. Jumlah penduduk Desa Lohia menurut data BPS tahun 2008 adalah 2.108 jiwa dengan tingkat kepadatan penduduk 256 $\mathrm{km}^{2}$, yang terdiri dari laki-laki sebanyak 998 jiwa dan perempuan sebanyak 1.110 jiwa. Jumlah kepala keluarga (KK) sebanyak 433 dengan rata-rata 5 jiwa perrumah tangga.

Sebagian besar penduduk Desa Lohia bermata pencaharian sebagai nelayan. Mereka melaut pada malam atau dini hari, ketika sebagian besar orang sedang tidur. Hal ini menyebabkan rendahnya pendidikan di banyak komunitas nelayan, terutama komunitas nelayan negara berkembang. Bahkan, di daerah yang tidak terlalu terisolasi, kesibukan bermata pencaharian menyebabkan mereka bersikap apatis terhadap pendidikan formal, bahkan sampai-sampai bersikap negatif jika dibandingkan dengan masyarakat yang bukan nelayan. Sebagai contoh, ketidakmampuan ekonomi sebagian anak-anak nelayan untuk berpakaian seragam sekolah secara layak mendorongnya cepat berhenti bersekolah.

Di kawasan timur Indonesia, Pulau Muna khususnya penduduk Desa Lohia, tidak berbeda budayanya dengan mereka yang juga bermata pencaharian sebagai nelayan. Misalnya suku Bugis, suku Makasar, dan suku Buton ketiganya dikenal sebagai suku maritim. Kemiripan budaya suku Muna dengan ketiga suku itu dapat dilihat cara pembuatan perahu, pantangan-pantangan yang tidak boleh dilanggar oleh nelayan, dan ritual peresmian perahu baru yang akan diturunkan melaut.

Masyarakat nelayan selalu memiliki ciriciri budaya bermasyarakat dalam kehidupan keseharian mereka. Pada situasi dan kondisi tertentu, karakteristik budaya mereka dapat digeneralisasikan. Namun, dengan adanya perubahan sosial religius dan perkembangan era informasi dan teknologi, sebagian karakteristik budaya mereka luntur. Berikut ini diuraikan sejumlah karakteristik masyarakat nelayan, yang terkait dengan etika dan budaya umum, yang selama ini masih sering ditemui. Setidak-tidaknya, ini menjadi salah satu wacana lingkungan pedesaan.

Kebiasaan bertegur sapa, saling mengunjungi, saling mengirim makanan belum hilang dalam keseharian. Kehidupan religius pun masih tampak kuat. Pada sore hari misalnya anak-anak nelayan pergi ke mushola untuk belajar agama islam. Kumandang azan masih selalu mampu memanggil warga mendirikan shalat berjamaah.

Sebagai masyarakat yang bertradisi bahari dan menggatungkan kehidupan di laut, pola pemukimannya berbentuk rumah panggung yang berjajar dan menghadap ke satu jalan umum atau jalan besar. Secara umum, pembangunan rumah tidak jauh berbeda arsitekturnya dengan rumah masyarakat Bugis Bone, di Sulawesi Selatan. Bentuk ruang dan fungsi rumah tergambar sebagai berikut. Kolong rumah, ruang yang ada di bawah ini lazimnya digunakan sebagai tempat penyimpan kayu bakar, dan alat-alat kerja. Ruang yang lain adalah ruangan dibagian atas, yang untuk mencapainya digunakan tangga kayu. Ruangan ini terdiri dari tiga petak yang disekat-sekat menurut kebutuhan, misalnya, ruang tamu, ruang keluarga, dan ruang belakang yang dijadikan kamar tidur. Pada ruangan yang lain lagi adalah loteng; yang berfungsi sebagai tempat menyimpan barang-barang berharga yang tidak digunakan sehari-hari. Berikut ini akan diuraikan berapa aspek sosial budaya yang memiliki pengaruh terhadap pembangunan.

a) Sistem Kekerabatan dan Pola Perkawinan.

Aspek-aspek budaya Pulau Muna dari masa ke masa, merupakan bagian integral yang tidak terpisahkan secara parsial, dalam ritual dinamikanya. Aspek-aspek budaya tersebut adalah stratifikasi sosial, sistem kekerabatan, dan agama. Kekerabatan adalah 
hubungan sosial yang terjadi antara seseorang dengan keluarganya, baik yang berjalur ayah maupun ibunya. Sistem kekerabatan merupakan kerangka interaksi antar-individu yang merasa memiliki pertalian persahabatan. Sistem kekerabatan bukan hanya berupa ikatan perkawinan atau hubungan kekeluargaan, tetapi juga karena adanya hubungan darah. Kunci pokok sistem perkawinan berupa kelompok keturunan atau line-age dan garis keturunan atau descent. Anggota kelompok keturunan saling berkaitan karena memiliki nenek moyang sama. Kelompok keturunan ini dapat bersifat patrilineal, matrilineal, atau bilineal

\section{b. Solidaritas Sosial}

Sikap solidaritas masyarakat pelaut dan nelayan sedikit banyak dilandasi oleh karakter masyarakat desa yang bernilai kekeluargaan (familism). Artinya, masyarakat desa masih tercermin nilai kekeluargaan yang tinggi karena eratnya keakraban antar mereka yang memiliki pertalian kekerabatan. Solidaritas bermasyarakat dimanifestasikan dalam istilah hidup; "Pokadulu" (gotong royong). Pokadulu merupakan bentuk kerja sama atau partisipasi warga dalam membangun desa dan berkegiatan keagamaan. Pokadulu merupakan wujud kearifan lokal yang terimplikasi pada setiap proses pembangunan desa.

c. Sarana dan Prasarana

Pendidikan merupakan modal dasar bagi pembangunan masyarakat.Tingkat dan kualitas pendidikan seseorang mempengaruhi kualitas sumber daya manusia. Pendidikan merupakan salah satu indikator kualitas sumber daya manusia yang menentukan gerak roda pembangunan masyarakat. Untuk meningkatkan sumber daya manusia diperlukan sarana dan prasarana pendidikan yang memadai.
Sarana pendidikan di Desa Lohia pada tahun 2008 tercatat, TK 1 unit. Sekolah Dasar 3 unit yaitu SDN 13 Lohia, SDN 7 Lohia, dan SDN Kecil Napabale.

Transportasi Antar Wilayah

Prasarana dan transportasi merupakan salah satu faktor pendukung bagi mobilitas penduduk. Permukaan jalan yang menghubungkan antar wilayah kecamatan pada umumnya baik karena telah diaspal. Jalan merupakan prasarana penting untuk memperlancar kegiatan perekonomian. Semakin meningkat usaha pembangunan, semakin ditingkatkan pula pembangunan jalan untuk memudahkan mobilitas penduduk, memperlancar transportasi antar daerah, dan mempermudah kunjungan wisatawan dari dan ke lokasi obyek-obyek wisata.

\section{Partisipasi Masyarakat dalam PNPM-MP.}

Partisipasi masyarakat dalam proses pembangunan wilayah merupakan keterlibatan mereka dalam setiap proses, baik langsung maupun tidak langsung. Partisipasi itu terwujud berdasarkan kemampuan yang dimiliki, semangat kerja sama, kelancaran penyampaian informasi atau sosialisasi program, penggalian gagasan dan perencanaan, pelaksanaan, pengawasan, pemanfaatan, dan pengembangan program sebagai wujud tanggung jawab warga masyarakat. Bentuk partisipasi warga masyarakat dalam kegiatan pembangunan merupakan kontribusi yang diberikannya untuk membantu dan mendukung berhasilnya setiap rencana dan pembangunan. Hal itu diwujudkan melalui sumbangan ide/ pemikiran, usul/gagasan, tenaga, materi, uang, waktu, lahan, dan keahlian/keterampilan.

Partisipasi warga masyarakat dalam pelaksanaan Program Nasional Pemberdayaan Masyarakat Mandiri Perdesaan (PNPM-MP) dapat dijelaskan sebagai berikut: 
a. Perencanaan Kegiatan

Indikator yang digunakan untuk mengukur tingkat partisipasi warga masyarakat dalam tahap perencanaan program adalah tingkat kehadirannya dalam pertemuan musyawarah di lingkup desa dan kotribusi mereka dalam memberikan masukan ide, saran, atau gagasan. Rekapitulasi data hasil kuesioner tingkat partisipasi warga masyarakat untuk hadir dalam memberikan kontribusi penilaian pada tahapan perencanaan Program Nasional Pemberdayaan Masyarakat Mandiri Perdesaan (PNPM-MP) akan dijelaskan dalam hasil analisis dengan statistik deskriptif. Dalam penelitian ini data pada tahap-tahap variabel meliputi nilai rata-rata, standar deviasi, distribusi frekuensi, dan persentase. Kriteria yang digunakan untuk menentukan kategori terikat untuk analisis deskriptif berpedoman pada kelompok tinggi, kelompok sedang, dan kelompok rendah. Seorang ahli ${ }^{7}$ menyatakan bahwa jika $Y>\hat{Y}+$ SD tergolong tinggi, jika $\hat{Y}-\mathrm{SD}<\mathrm{Y}<\hat{Y}+\mathrm{SD}$ tergolong kelompok sedang, dan jika $\mathrm{Y}<\hat{Y}-\mathrm{SD}$ tergolong kelompok rendah, data menunjukan bahwa nilai rata-rata (mean) pada tahap perencanaan sebesar 1,950 dengan standar deviasi 0,642.

Berdasarkan hasil analisis data deskriptif, tingkat partisipasi responden pada tahap perencanaan dalam penelitian ini tercatat kategori rendah $28 \%$, kategori sedang $56 \%$, dan kategori tinggi $16 \%$. Data ini memberikan gambaran bahwa partisipasi masyarakat dalam tahap perencanaan pada Program Nasional Pemberdayaan Masyarakat Mandiri Perdesaan (PNPM-MP) di Desa Lohia tergolong sedang.

Arikunto, S. 2009. Dasar-dasar evaluasi pendidikan (edisi refisi). Bumi Aksara. Jakarta. b. Pelaksanaan Kegiatan

Partisipasi masyarakat dalam tahap pelaksanaan, yang telah dicanangkan pada tahap perencanaan, dan disetujui untuk dibiayai serta dilaksanakan pada waktunya diukur dari tingkat kehadiran untuk memberikan kontribusi, baik waktu, materi maupun bahan. Rekapitulasi data hasil kuesioner tingkat partisipasi masyarakat dalam memberikan kontribusi dalam pelaksanaan program adalah nilai rata-rata (mean) pada tahap pelaksanaan sebesar 2,080 dengan standar deviasi 0,646.

Berdasarkan hasil analisis data deskriptif, tingkat partisipasi responden pada tahap pelaksanaan dalam penelitian ini tercatat kategori rendah 17\%), kategori sedang $58 \%$, dan kategori tinggi $25 \%$. Data ini memberikan gambaran bahwa partisipasi masyarakat dalam tahap pelaksanaan pada Program Nasional Pemberdayaan Masyarakat Mandiri Perdesaan (PNPM-MP) di Desa Lohia tergolong sedang.

Dalam pelaksanaan kegiatan PNPM-MP, partisipasi warga masyarakat lebih dominan dalam bentuk tenaga sebagai akibat dari dilibatkannya kelompok masyarakat kurang mampu dalam pelaksanaan program. Kesuksesan pelaksanaan PNPM-MP tersebut lebih diutamakan pada pemberdayaan kelompok rumah tangga miskin (RTM).

c. Pengawasan Kegiatan

Tingkat keaktifan warga masyarakat dalam memantau dan mengawasi pelaksanaan program dan melaporkan tindakan yang tidak sesuai dengan rencana yang telah ditetapkan dalam setiap kegiatan menunjukkan bahwa nilai rata-rata (mean) pada tahap pengawasan sebesar 2,020 dengan standar deviasi 0,651.

Berdasarkan hasil analisis data deskriptif, tingkat partisipasi responden pada tahap pengawasan program tercatat kategori rendah $20 \%$, kategori 
sedang 58\%, dan kategori tinggi $22 \%$. Data ini memberikan gambaran bahwa partisipasi masyarakat dalam tahap pengawasan Program Nasional Pemberdayaan Masyarakat Mandiri Perdesaan (PNPM-MP) di Desa Lohia berkategori sedang.

d. Pemanfaatan Kegiatan

Pada tahap pemanfaatan indikator yang digunakan berdasarkan frekuensi penggunaan sarana yang telah dibangun serta keikutsertaan mereka dalam kegiatan kegiatan pemeliharaan bersama-sama warga masyarakat lainnya. Data menunjukkan bahwa nilai rata-rata (mean) pada tahap pemanfaatan sebesar 2,100 dengan standar deviasi 0,674 .

Berdasarkan hasil analisis data deskriptif, tingkat partisipasi responden pada tahap pemeliharaan dan pemanfaatan program tercatat kategori rendah $18 \%$, kategori sedang $54 \%$, dan kategori tinggi 28\%. Data ini memberikan gambaran bahwa partisipasi masyarakat dalam tahap pelaksanaan Program Nasional Pemberdayaan Masyarakat Mandiri Perdesaan (PNPMMP) di Desa Lohia berkategori sedang.

e. Tingkat Partisipasi Warga Masyarakat. Desa Lohia dengan keterbatasan infrastruktur dan kondisi sosial ekonomi masyarakat yang heterogen memperlihatkan tingkat partisipasi warga masyarakat yang juga sangat tergantung terhadap intervensi program pemberdayaan dari pemerintah. Seorang ahli ${ }^{8}$ mengatakan bahwa daerah tidak berkembang ketika ketersediaan infrastruktur sangat terbatas, tingkat partisipasi masyarakat sangat rendah, serta cenderung mengharapkan dan tergantung pada intervensi program pemerintah, sumber daya alam

Wults. F.R. 1990. Grand Strategy for Community Base Development (CBD). Direktorat Perkotaan dan Pedesaan. Bappenas. Jakarta. setempat, dan tingkat penyesuaiannya dengan situasi dan kondisi setempat. Keterlibatan warga masyarakat dalam pengembangan pariwisata berdasarkan tahapan-tahapan pelaksanaan Program Nasional Pemberdayaan Masyarakat Mandiri Perdesaan (PNPM-MP) pada tahun anggaran 2009 adalah sebagai berikut. Data yang merupakan hasil analisis dengan statistik deskriptif menunjukkan bahwa nilai rata-rata $\hat{Y}$ sebesar 2,170 dengan standar deviasi 0,604 .

Berdasarkan hasil analisis data deskriptif, tingkat partisipasi responden pada pengembangan pariwisata tercatat kategori rendah 11\%, kategori sedang $61 \%$, dan kategori tinggi $28 \%$. Berdasarkan data ini memberikan gambaran bahwa tingkat partisipasi masyarakat secara keseluruhan dalam pengembangan pariwisata melalui Program Nasional Pemberdayaan Masyarakat Mandiri Perdesaan (PNPM-MP) di Desa Lohia berkategori sedang.

\section{Analisis Statistik Inferensial}

Pengaruh Variabel Sanitasi, Umur, Pendidikan, Ormas, dan Pendapatan secara Parsial terhadap Variabel Tingkat Partisipasi Masyarakat.

a) Pengaruh Sanitasi terhadap Tingkat Partisipasi Masyarakat.

Hasil analisis menunjukkan bahwa koefisien korelasi yang dihasilkan adalah $r=0,242$. Terdapat hubungan yang berpengaruh lemah positif antara variabel sanitasi terhadap tingkat partisipasi dalam pengembangan pariwisata.

Berdasarkan hasil olahan data diketahui t hitung sebesar 2,473 dan signifikan 0,015. Karena $t$ hitung $>t$ tabel, yaitu 2,473 > 1,982, dapat disimpulkan bahwa terdapat pengaruh positif dan signifikan antara sanitasi terhadap tingkat partisipasi pengembangan pariwisata. Dengan demikian, hipotesis penelitian yang berbunyi 
bahwa semakin baik sanitasi seseorang, semakin meningkat pula partisipasi dalam pengembangan pariwisata terbukti. Adapun sumbangan pengaruhnya (koefisien determinasi) adalah $\mathrm{r}$ Square $\left(r^{2}\right)$ sebesar 0,040 atau sebesar $4 \%$.

Hal ini sesuai dengan observasi di lapangan bahwa pembuangan air limbah rumah tangga yang tidak teratur di kolong-kolong rumah tampak air menggenang dan lembab. Menjadikan media yang sangat baik bagi pertumbuhan berbagai bakteri dan sumber penyakit. Bahkan, masih banyak warga masyarakat yang tidak memiliki WC keluarga. Mereka sering membuang kotoran di sekitar rumah dengan cara membuat lubang kecil di tanah dan setelah digunakan untuk buang air besar, lubang itu ditutup.

Pembuangan kotoran dalam lubang kecil di tanah ini mudah dibongkar oleh hewan, seperti anjing, sehingga kotoran itu mencemari air yang dikonsumsi oleh warga masyarakat sekitar. Kesadaran warga masyarakat terhadap kualitas kesehatan mereka sendiri dapat diwujudkan bilamana mereka menyadari dan mengerti pentingnya kebersihan lingkungan.

b. Pengaruh Umur terhadap Tingkat Partisipasi Warga Masyarakat.

Hasil analisis menunjukkan bahwa koefisien korelasi yang dihasilkan adalah $\mathrm{r}=0,055$. Dapat dikatakan bahwa terdapat hubungan yang berpengaruh sangat lemah positif antara variabel umur terhadap tingkat partisipasi warga masyarakat dalam pengembangan pariwisata.

Berdasarkan hasil olahan data diketahui $t$ hitung sebesar 0,540 dan signifikan 0,590. Karena $\mathrm{t}$ hitung $<\mathrm{t}$ tabel, yaitu 0,540<1,982, dapat disimpulkan bahwa tidak terdapat pengaruh positif namun tidak nyata antara umur terhadap tingkat partisipasi warga masyarakat dalam pengembangan pariwisata. Dengan demikian, hipotesis penelitian yang berbunyi bahwa semakin produktif umur seseorang, semakin meningkat pula partisipasi warga masyarakat dalam pengembangan pariwisata tidak terbukti. Adapun sumbangan pengaruhnya (koefisien determinasi) adalah $\mathrm{r}$ Square $\left(\mathrm{r}^{2}\right)$ sebesar 0,003 atau $0,3 \%$.

Berdasarkan hasil analisis di atas faktor umur berpengaruh sangat lemah positf, namun tidak nyata terhadap tingkat partisipasi masyarakat dalam pengembangan pariwisata melalui program PNPM-MP. Hal ini menunjukkan bahwa tidak ada perbedaan antara usia produktif dengan usia muda dan usia tua terhadap tingkat partisipasi warga masyarakat dalam pengembangan pariwisata.

c. Pengaruh Tingkat Pendidikan terhadap Tingkat Partisipasi Masyarakat.

Hasil analisis menunjukkan bahwa koefisien korelasi yang dihasilkan adalah $r=0,446$. Dapat dikatakan bahwa terdapat hubungan yang berpengaruh sedang positif antara variabel tingkat pendidikan terhadap tingkat partisipasi warga masyarakat dalam pengembangan pariwisata.

Berdasarkan hasil olahan data diketahui t hitung sebesar 4,936 dan signifikan 0,000. Karena $\mathrm{t}$ hitung $>\mathrm{t}$ tabel, yaitu 4,936 > 1,982, dapat disimpulkan bahwa terdapat pengaruh positif dan signifikan antara tingkat pendidikan terhadap tingkat partisipasi warga masyarakat dalam pengembangan pariwisata. Dengan demikian, hipotesis penelitian yang berbunyi bahwa semakin tinggi pendidikan seseorang, semakin meningkat pula partisipasi masyarakat dalam pengembangan pariwisata terbukti. Adapun sumbangan pengaruhnya (koefisien determinasi) adalah $\mathrm{r}$ Square $\left(\mathrm{r}^{2}\right)$ sebesar 0,199 atau $19,9 \%$. 
d. Pengaruh Organisasi Kemasyarakatan terhadap Tingkat Partisipasi Masyarakat.

Hasil analisis menunjukkan bahwa koefisien korelasi yang dihasilkan adalah $\mathrm{r}=0,426$. Dapat dikatakan bahwa terdapat hubungan yang berpengaruh sedang positif antara variabel organisasi kemasyarakatan terhadap tingkat partisipasi warga masyarakat dalam pengembangan pariwisata.

Berdasarkan hasil olahan data diketahui t hitung sebesar 4,668 dan signifikan 0,000. Karena $\mathrm{t}$ hitung $>\mathrm{t}$ tabel, yaitu 4,668 >1,982, dapat disimpulkan bahwa terdapat pengaruh secara signifikan antara keterlibatan responden dalam organisasi kemasyarakatan terhadap tingkat partisipasi masyarakat dalam pengembangan pariwisata. Dengan demikian, hipotesis penelitian yang berbunyi bahwa semakin aktif seseorang dalam organisasi kemasyarakatan, semakin meningkat pula partisipasi warga masyarakat dalam pengembangan pariwisata terbukti. Adapun sumbang pengaruhnya (koefisien determinasi) adalah $r$ Square $\left(r^{2}\right)$ sebesar 0,182 atau sebesar $18,2 \%$.

e. Pengaruh Pendapatan terhadap Tingkat Partisipasi Masyarakat.

Hasil analisis menunjukkan bahwa koefisien korelasi yang dihasilkan adalah $r=0,220$. Dapat dikatakan bahwa terdapat hubungan yang berpengaruh lemah positif antara variabel pendapatan terhadap tingkat partisipasi dalam pengembangan pariwisata. Berdasarkan hasil olahan data diketahui thitung sebesar 2,238 dan signifikan 0,027. Karena t hitung $>\mathrm{t}$ tabel, yaitu 2,238 > 1,982, dapat disimpulkan bahwa terdapat pengaruh secara signifikan antara pendapatan terhadap tingkat partisipasi warga masyarakat dalam pengembangan pariwisata. Dengan demikian, hipotesis penelitian yang berbunyi bahwa semakin tinggi pendapatan seseorang, semakin meningkat pula partisipasi warga masyarakat dalam pengembangan pariwisata terbukti. Adapun sumbang pengaruhnya (koefisien determinasi) adalah $\mathrm{r}$ Square $\left(\mathrm{r}^{2}\right)$ sebesar 0,049 atau sebesar $4,9 \%$.

Pengaruh Variabel Sanitasi, Umur, Pendidikan, Ormas dan Pendapatan secara Bersama-sama terhadap Variabel Tingkat Partisipasi Warga Masyarakat.

Hasil analisis menunjukkan bahwa koefisien korelasi yang dihasilkan adalah $\mathrm{R}=0,595$. Dapat dikatakan bahwa terdapat hubungan yang berpengaruh sedang positif antara variabel bebas faktor lingkungan fisik dan faktor sosial-ekonomi terhadap tingkat partisipasi warga masyarakat dalam pengembangan pariwisata.

Berdasarkan hasil olahan data diketahui koefisien atau $\mathrm{R}=0,595$, pada tabel Anova terlihat bahwa nilai $\mathrm{F}=$ 10,278 dan signifikansi $F=0,000$. Karena F hitung $>$ F tabel, yaitu 10,278 $>3,093$ dan signifikan $0,000<0,05$, dapat disimpulkan bahwa terdapat pengaruh sedang secara positif dan signifikan antara faktor lingkungan fisik, faktor sosial budaya dan faktor sosial-ekonomi secara bersama-sama terhadap tingkat partisipasi warga masyarakat dalam pengembangan pariwisata di Desa Lohia. Dengan demikian, hipotesis penelitian yang berbunyi bahwa semakin baik sanitasi, semakin produktif usia, semakin tinggi pendidikan, semakin aktif dalam organisasi kemasyarakatan dan semakin tinggi tingkat pendapatan, semakin tinggi pula tingkat partisipasi masyarakat dalam pengembangan pariwisata di Desa Lohia terbukti. Hasil analisis juga menunjukkan bahwa kemungkinan kesalahan untuk menolak hipotesis tersebut adalah sebesar $0 \%$ sebagaimana yang ditunjukkan pada F Signifikan atau probabilitas yaitu sebesar 0,000 . 
Adapun sumbang' pengaruhnya (koefisien determinasi) adalah R Square $\left(R^{2}\right)$ sebesar 0,353 atau 35,3\%. Berdasarkan hasil analisis regresi ganda tingkat partisipasi warga masyarakat dipengaruhi oleh faktor sanitasi, umur, pendidikan, organisasi kemasyarakatan dengan koefisien regresi $(\mathrm{Y}=0,509+$ $0,201 X_{1}+0,152 X_{2}+0,451 X_{3}+0,224 X_{4}+$ $\left.0,006 \mathrm{X}_{5}\right)$.

\section{KESIMPULAN DAN SARAN}

\section{Kesimpulan}

(1). Warga Masyarakat di Desa Lohia yang dijadikan responden dalam penelitian ini sebagian besar berkondisi fisik lingkungan kategori sedang $61 \%$, berjenis kelamin lakilaki $76 \%$, berumur antara 35-45 tahun 64\%, bertingkat pendidikan tidak tamat SD - tamat SD 53\%, bukan sebagai pengurus/anggota organisasi kemasyarakatan $75 \%$, dan berpendapatan rata-rata antara Rp500.000 s/ d Rp999.000 dan berpekerjaan wiraswasta $77 \%$.

(2). Tingkat partisipasi masyarakat dalam pengembangan pariwisata melalui PNPMMP di Desa Lohia berkategori sedang sebesar $61 \%$.; (3). Terdapat pengaruh lemah positif dan signifikan antara sanitasi terhadap tingkat partisipasi warga masyarakat dalam pengembangan pariwisata $(\mathrm{r}=0,242)$ dengan sumbangan pengaruh sebesar $r^{2}=0,05,9$ atau $5,9 \%$. (4). Terdapat pengaruh sangat lemah positif namun tidak nyata antara umur terhadap tingkat partisipasi warga masyarakat dalam pengembangan pariwisata $(r=0,055)$ dengan sumbangan pengaruh $\mathrm{r}^{2}=0,003$ atau $0,3 \%$. (5). Terdapat pengaruh lemah positif dan signifikan antara pendidikan terhadap tingkat partisipasi warga masyarakat dalam pengembangan pariwisata $(r=0,446)$ dengan sumbangan pengaruh sebesar $r^{2}=0,199$ atau $19,9 \%$. (6). Terdapat pengaruh lemah positif dan signifikan antara organisasi kemasyara- katan terhadap tingkat partisipasi masyarakat dalam pengembangan pariwisata $(r=0,426)$ dengan sumbangan pengaruh $\mathrm{r}^{2}=0,182$ atau $18,2 \%$. (7). Terdapat pengaruh lemah positif dan signifikan antara pendapatan terhadap tingkat partisipasi warga masyarakat dalam pengemba-ngan pariwisata $(r=0,220)$ dengan sumbangan pengaruh sebesar $r^{2}=0,049$ atau $4,9 \%$. (8). Secara bersama-sama lima variabel bebas berpengaruh sedang positif dan signifikan terhadap tingkat partisipasi warga masyarakat dalam pengembangan pariwisata melalui Program Nasional Pemberdayaan Masyarakat Mandiri Perdesaan (PNPM-MP), dengan nilai koefisien korelasi sebesar $\mathrm{R}=$ 0,595 dan sumbangan pengaruhnya sebesar $\mathrm{R}^{2}=0,353$ atau $35,3 \%$. (9). Tingkat partisipasi masyarakat terhadap pelaksana-an program dipengaruhi oleh faktor lingkungan fisik, sosial-budaya, dan sosial-ekonomi, seperti sanitasi, umur, pendidikan, organisasi kemasyarakatan, dan pendapatan $(\mathrm{Y}=0,509$ $+0,201 X_{1}+0,152 X_{2}+0,451 X_{3}+0,224 X_{4}+$ $\left.0,006 \mathrm{X}_{5}\right)$.

\section{Saran}

(1). Perlu diadakan pelatihan keterampilan dan penguatan lembaga/institusi di tingkat desa yang berkaitan dengan pengembangan pariwisata karena faktor pendidikan dan organisasi kemasyarakatan dalam penelitian ini memberikan sumbangan terbesar dibandingkan dengan faktor lain. (2). Diperlukan keterlibatan berbagai pihak untuk meningkatkan partisipasi warga masyarakat, antara lain, kesadaran masyarakat itu sendiri, Pemerintah Kabupaten Muna yang bekerja sama dengan dinas terkait, perguruan tinggi, dan LSM, dengan tetap mengingat betapa besarnya biaya yang diperlukan untuk mengembangkan kawasan wisata di Desa Lohia, sedangkan kemampuan pemerintah daerah terbatas. 


\section{DAFTAR PUSTAKA}

Arikunto, S. 1998. Prosedur Penelitian. PT. Rineka Cipta. Jakarta.

Bappenas, 2003. Kebijakan Nasional Pembangunan Sarana Air Bersih dan Penyehatan Lingkungan Berbasis Pengelolaan Masyarakat. Bappenas. Jakarta.

Damanik, J., Weber, HF. 2006. Perencanaan Ekowisata dari Teori ke Aplikasi. Pusat Studi Pariwisata UGM dan Andi.Yogyakarta.

Kustiah, T. 2005. Pengelolaan Sanitasi Berbasis Masyarakat. Kolokium. Bandung.
Kusmayadi. 2004. Statistika Pariwisata Deskriptif. Prenhallindo. Jakarta.

Mantra, I. B., Kasto. 1989. Metode Penelitian Survey. Singarimbun, M., Effendi. S. ed. LP3ES. Yogyakarta.

Singarimbun, M., Efendi, S. 1995. Metode Penelitian Survey. LP3ES. Yogyakarta.

Sugiyono. 2007. Statistika untuk Penelitian. Alfabeta. Bandung.

Sulistiyani. 2004. Kemitraan dan ModelModel Pemberdayaan. Gaya Media. Yogyakarta

Wults. F. R. 1990. Grand Strategy for Community Base Development (CBD). Direktorat Perkotaan dan Pedesaan. Bappenas. Jakarta. 